\title{
The semiotics of models
}

\author{
Winfried Nöth \\ Programa de Estudos Pós-Graduados em \\ Tecnologias da Inteligência e Design Digital \\ Pontifícia Universidade Católica de São Paulo \\ Rua Caio Prado, 102 - Consolação \\ CEP 01303-000 São Paulo, Brazil \\ e-mail: wnoth@pucsp.br
}

\begin{abstract}
The paper sheds light on the concept of model in ordinary language and in scientific discourse from the perspective of C. S. Peirce's semiotics. It proposes a general Peircean framework for the definition of models of all kinds, including mental models. A survey of definitions of scientific models that have been influential in the philosophy of science and of the typologies proposed in this context is given. The author criticizes the heterogeneity of the criteria applied in these typologies and the lack of a semiotic foundation in typological distinctions between formal, symbolic, theoretical, metaphorical, and iconic models, among others. The paper argues that the application of Peirce's subdivision of signs into the trichotomies of the sign itself, its object, and its interpretant can offer a deeper understanding of the nature of models. Semiotic topics in the focus of the paper are (1) the distinction between models as signs and (mental) models as the interpretants of signs; (2) models considered as a type (or legisign) and models considered as tokens (or replicas) of a type; (3) the iconicity of models, including diagrammatic and metaphorical icons; (4) the contribution of indices and symbols to the informativity of models; and (5) the rhetorical qualities of models in scientific discourse. The paper argues in conclusion that informative models are hybrid signs in which a diagram incorporates indices and symbols in a rhetorically efficient way.
\end{abstract}

Key words: model; diagram; metaphor; icon; legisign; type; token; C. S. Peirce

Concepts such as 'representation', 'likeness', 'icon', 'metaphor', or 'symbol' in the diverse descriptions of models in general and scientific models in particular are key notions of Peirce's semiotics, but few philosophers of science have acknowledged their debt to Peircean semiotics. Max Black mentions Peirce only briefly in Models and Metaphors (1962), restricting his reference to Peirce's concept of icon in its most rudimentary 
form. Rom Harré adopts from Peirce the dichotomy of type vs. token as a key concept of his book Modeling: Gateway to the Unknown (2004), but he does not mention Peirce at all. Hence, it seems worthwhile to shed some light on the nature of the concept of model from Peirce's semiotic perspective. What does Peirce, who did not discuss models explicitly, have to say about models as representations in general, models as types, and, in particular, about diagrammatic models?

In recent approaches to the study of the concept of 'model' in scientific discourse, Peirce's semiotics and his philosophy of science have been sources of inspiration for several authors (Magnani et al. 2010; Kralemann, Lattmann 2013; Zeidler 2013: 124134; Ciula, Eide 2017; Magnani, Bertolotti 2017). Most of their studies have focused on Peirce's notion of the diagram. The present paper aims at filling the gaps that these studies have left in the endeavour to explore the full potential of Peirce's semiotics in the study of models in science and in ordinary language use.

\section{Models as signs or representations}

A model is a representation and a representation is a sign, but how do models represent, and what do they represent? Are models signs in all of the various meanings of the word? What is it that makes a model a sign?

\subsection{Meanings of the word 'model' in ordinary language}

The word 'model' is polysemous. The main meanings distinguished by the Oxford Dictionary of English (ODE) for the noun are five:

(1) a three-dimensional representation of a person or thing, typically on a smaller scale: an architectural model;

(2) a person or plan worthy to be followed as an example: a model father;

(3) a simplified description, especially a mathematical one: a statistical model;

(4) a person employed to display clothes by wearing them: a fashion model;

(5) a particular design or version of a product: the most recent car model.

Common features of these definitions are that models 'represent something, 'are similar to', 'resemble, 'imitate, 'are best examples of', or 'types of' something. An architectural model is a physical representation of a building to which it is similar except for size. A simplified description represents an object domain (person, thing, event) in the form of a verbal message. A description is similar to its object in a different way, not physically, but through the mental images it creates. 
A pattern for imitation serves as a type to create objects similar to it. The most recent car model is a type of product. A model father is a best example of a father, who serves to exemplify a type. A model town serves as a type worth imitating; it is the instance of a type. Towns that follow its model are instances of this model and, at the same time, become similar to it to the degree in which they adopt its features. Fashion models are instances of a type in a different sense. Chosen for their good looks (according to the current cultural fashion), these persons are the epitome of the good-looking ones, and their clothes represent the season's type of clothes in fashion.

\subsection{Models as signs and Peirce's definition of signs}

Sign and representation are quasi-synonyms in most of Peirce's writings. Sometimes, the alternative term for both is representamen. In 1904, Peirce wrote, “'Representation' and 'sign' are synonyms" (CP 8.191). Thus, if a model is a representation it is also a sign according to Peirce.

A sign, for Peirce, may be a material thing, for "a thing which stands for another thing is a representation or sign" (CP 7.355, 1873). However, thoughts and mere ideas are signs, too: "We apply the word 'sign' to everything recognizable whether to our outward senses or to our inward feeling and imagination, provided only it calls up some feeling, effort, or thought" (MS 678: 23, 1910). When Peirce defines the sign in this way as a material or mental object, his definition is clearly applicable to the distinction between material and mental models (see below).

A sign, according to Peirce, 'represents' an object, but the object is not its 'referent'. It is simply "the object of a sign", a material thing, a mere idea, a thought, or even something only "believed formerly to have existed or expected to exist", or "something of a general nature" and not material in any sense (CP 2.232, 1910). What is the object of a sign that serves as a model? Among the characteristics addressed by the various authors are "something else", an "original", an "object" (of imitation), or "a domain of less known knowledge".

The interpretant of a sign (i.e., its 'meaning') is, very broadly, the translation of the sign "into another sign in which it is more fully developed" (CP 5.594, 1903). It is hence more informative than the sign itself (cf. Nöth 2014). The interpretant is more developed than the sign it interprets because "it is of the nature of thought to grow" in the process of interpretation (CP 2.32, c. 1902). Insofar as a model interprets signs, it has the function of an interpretant to be more informative that the object domain it interprets. 


\subsection{Models as types and replicas of types: A first approach}

Insofar as a model serves as a type, a pattern of which replicas exist or can be produced, it belongs to a kind of sign that Peirce defines as 'type' or 'legisign' (CP 2.246, 1893). As a type, a model is embodied in instances of this type called replicas or tokens. The distinction between a type and its tokens is similar to Saussure's distinction between 'langue' and 'parole' (language and speech). A word, considered as an element of a language is a type. As such, it exists, so to speak, only once, for example, the article 'the' in English as an element of the language system. Considered from the perspective of parole or speech, i.e., as an individually occurring instance of the type, it is a token. The most recent car model is a type; the cars of this type actually existing on the market are tokens, also called replicas, of this type. A toy car is the replica of a toy car model (of a brand).

Types and icons are not mutually exclusive classes of signs. The same sign can be both icon and type. Peirce defines a sign that is both a type and an icon as an iconic legisign, which is one of the three classes of legisigns besides the indexical and the symbolic ones. Models cannot be indexical legisigns because indices only indicate without representing their object. The compatibility of icons with types is apparent when the concept of 'type' is defined in terms of the similarity of its members, for example, as a "group of [...] things that share similar characteristics" $\left(\mathrm{CDE}^{1}\right)$. However, while all models are both representations and types, some models, for instance, formal or theoretical ones, look hardly similar to what they represent because they are exclusively, or predominantly, formulated verbally. These models are symbolic legisigns.

\subsection{The so-called symbolic models}

Rosenblueth and Wiener (1945) define formal models as models that use "symbolic (i.e., mathematical) assertions in logical terms". The very term 'symbolic' suggests that formal models are conceived as symbolic signs. When Black (1962) conceives of a mathematical model as a model formulated in the language of mathematics, he suggests the same insofar as a language is a system of conventional signs and hence of symbols. Pola et al. (2015: 2328) follow this tradition of defining symbolic models as "abstract models where each symbolic state and each symbolic label represents an aggregation of continuous states". Models formulated in the form of a verbal text are symbols. Theoretical models may not have any illustration at all. Insofar as they consist of verbal signs, they are symbols.

$1 \mathrm{CDE}=$ Cambridge Dictionary of English Online, https://dictionary.cambridge.org/ dictionary/english/. Accessed in December 2017. 
Ouliaris $^{2}$ gives an example to illustrate the nature of theoretical models that are mere "simplified descriptions" in an article under the title "Economic models: Simulations of reality":

The modern economy is a complex machine. Its job is to allocate limited resources and distribute output among a large number of agents - mainly individuals, firms, and governments - allowing for the possibility that each agent's action can directly (or indirectly) affect other agents' actions. Adam Smith labeled the machine the "invisible hand". In The Wealth of Nations, published in 1776, Smith, widely considered the father of economics, emphasized the economy's self-regulating nature - that agents independently seeking their own gain may produce the best overall result for society as well. Today's economists build models - road maps of reality, if you will - to enhance our understanding of the invisible hand. (Ouliaris 2017)

Formulated in words and thus symbols, Adam Smith describes what goes on in an economy in terms of a metaphor. Although Smith attributes invisibility to the hand that acts in his scenario, the author cannot help evoking the mental image of such a hand. His verbal metaphors need to be interpreted through the mediation of an imaginary icon. The iconicity inherent in his comparisons of an economy with a machine and an invisible hand differs from the one of graphic model. While a graphic model is an icon qua sign, Smith's metaphors consist of symbolic signs that turn into in the process of their interpretation (see Section 3.2).

\subsection{Outline of the full semiotic framework: Peirce's typology of signs}

A full account of the semiotic framework for the study of models needs to begin with an analysis of the three constituents of a sign: first, the sign itself; second, the object represented by the sign; and, third, the interpretant of the sign, which is the effect of the sign on its interpreter or the mode of its interpretation. The classification of signs from the perspectives of these three constituents results in three classes of triads that Peirce calls trichotomies (CP 2.243-53, 1903). A summary is the following:

(a) First trichotomy: the sign in itself

(1) Qualisign: the sign is a sign by its mere quality;

(2) Sinsign: the sign is a singular thing or the instance of a type;

(3) Legisign: the sign is a rule, norm, habit, or law.

2 Ouliaris, Sam 2017. Economic models: Simulations of reality. Finance \& Development Maga-

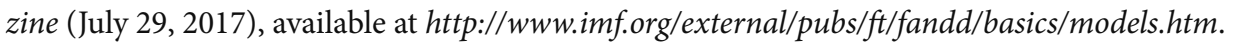


(b) Second trichotomy: the sign in relation to its object

(1) Icon: the sign is similar to its object;

(2) Index: the sign indicates its object, has a causal, temporal or spatial relation to it;

(3) Symbol: the sign is sign because of a habit; it must be learned; it is based on a convention.

(c) Third trichotomy: the sign in relation to its interpretant

(1) Rheme: the sign corresponds roughly to the predicate part of a proposition (with the subjects or objects omitted; e.g., -is happy, -is a girl, -runs, -loves). Like a word in isolation, a rheme can be neither true nor false. Its means something merely possible.

(2) Dicent or dicisign: the sign is interpreted like a proposition. It can be used to state a fact.

(3) Argument: the sign consists of premises that lead to a conclusion.

The possibilities of combining of the three trichotomies to specific types and certain restriction to the possibilities of combining the trichotomies result in Peirce's system of the ten main sign classes (CP 2.254-265, 1903). Four of the ten classes (III, IV, VI, and VII) are classified as indexical. A demonstrative pronoun, fire engine sirens, or church bells are examples of indexical legisigns, but such signs are not models because they only serve to indicate without representing anything, as models are required to do. The examples show that models cannot be indexical signs alone. Of the remaining six classes, the first is the one of the rhematic iconic qualisign (or simply qualisign).

In his paper "A Peircean classification of models", Nathan Houser does include qualisigns in his general typology of models as signs that "are essentially qualitative and represent, or model, objects by sharing or duplicating significant properties of those objects". The author gives two examples with the following justification, "A color sample models its color and a spoonful of sauce that a chef samples models the flavor of the sauce" (Houser 1991: 434). However, the inclusion of qualisigns in a typology of models is hardly convincing. A colour sample that exemplifies a specific shade of colour and a spoonful of sauce to exemplify a specific culinary flavour are usually not called 'models' but 'samples' in ordinary language usage. A brief look at their semiotic characteristics can show how samples differ from models and why they should not be included in a typology of models.

In Chapter II.3 of Languages of Art, Nelson Goodman (1976[1968]) proposes a semiotic theory of samples, defining them as a "mode of symbolization" that belongs to the class of exemplifications. A tailors' swatch is one of Goodman's favourite examples. The little sample piece of cloth has all the qualities of the roll of cloth from which the tailor can sew the suit, but it does not serve to denote the roll; it simply 
possesses the same features, such as colour and texture. Hence, while a model serves to represent its object domain, the sample does not.

Another reason why a genuine qualisign cannot be a model from the perspective of Peirce's semiotics, is that "a qualisign [...] cannot actually act as a sign until it is embodied" (CP 2.244, 1903), but whenever a qualisign is embodied it is an individual object. However, a specific object can only act as a sinsign. Nevertheless, the insight that qualisigns cannot be models does not mean that they are irrelevant to the study of models since any icon "embodies necessarily a qualisign" (CP 2.255) because it is a sign that shares qualities with its object.

In sum, if we subtract the four classes of indexical signs and the qualisign from Peirce's list of ten classes of signs, the following five classes of symbols or icons remain to be examined in this paper as possible semiotic characterizations of models (the Roman numbers are from Peirce's list of ten):

(1) (rhematic) iconic sinsign (II);

(2) (rhematic) iconic legisign (V);

(3) rhematic symbol (a legisign) (VIII);

(4) dicent symbol (a legisign) (IX);

(5) argument (a symbolic legisign) (X).

It remains to be examined whether there are actually two types of iconic and three types of symbolic models, but before we address this question (in Sections 3 and 4), the concepts of scientific and mental models will be examined in order to broaden the scope of the study of models.

\section{Scientific and mental models}

'Model' is a key concept in the philosophy of science. In cognitive science, in particular, the notion of 'mental model' has been in the centre of attention since the 1980s. What are the semiotic characteristics of scientific and mental models? How do philosophers of science define scientific models, how are mental models defined in cognitive science, and what kind of signs are these models?

\subsection{Scientific models: Definitions, types, and semiotic classification}

"The term model is heavily overloaded", declares Liddle (2011:21) in his article for the Handbook of Conceptual Modeling: "When we say 'model' [...] we mean a diagram or model instance that conforms to a particular modeling language". Despite the author's 
plea for a narrower definition of the term, the technical definition he proposes is not too different from the meaning of the word 'model' in ordinary language. If a model is a diagram, it is an iconic representation and if the study of models is a study of "instances", it is the study of instances of a type. Let us consider in more detail how models are defined and classified in the philosophy of science. What kinds of model do the philosophers of science distinguish?

An early influential paper on the role of models in science distinguishes between material and formal models:

A material model is the representation of a complex system by a system which is assumed simpler and which is also assumed to have some properties similar to those selected for study in the original complex system. A formal model is a symbolic assertion in logical terms of an idealized relatively simple situation sharing the structural properties of the original factual system. (Rosenblueth, Wiener 1945: 317)

Seen from the perspective of Peirce's semiotics, the distinction drawn here concerns different types of sign. As a sign defined by the "similar properties" that it shares with its object, a material model thus belongs to the iconic type. When the authors specify that a "material model may enable the carrying out of experiments under more favorable conditions than would be available in the original system" (Rosenblueth, Wiener 1945: 317), they describe models of the nature of a singular object. A material model in this definition is an iconic token or sinsign, defined as "an actual existent thing or event which is a sign" (CP 2.245, 1903). Since it is a sign due to its qualities (of form, shape, material, etc.), the iconic sinsign is at the same time an icon "through its qualities; so that it involves a qualisign, or rather, several qualisigns. But these qualisigns are of a peculiar kind and only form a sign through being actually embodied" (CP 2.245, 1903). In its full semiotic analysis, the material sign is thus an iconic sinsign that embodies a qualisign.

A material model can also be the replica of a legisign or type. An example is the latest car model of the season. In the sense of a material object, it is a faithful icon of its type, the car of the season. In the sense of a replica of a type, we use the word 'model' when we say, "She always drives the latest model". A replica is at the same time a sinsign, a sign in its singularity. The new model as a type, by contrast, has no materiality; it is the general pattern from which the cars for sale are modelled. The immaterial model of the year is the iconic legisign of which replicas (and hence sinsigns) are sold on the market. While the car as a replica of the most recent model may be destroyed in an accident, the type is thereby not destroyed.

Rosenblueth and Wiener's "formal model", defined as one that makes "symbolic assertions", is a symbolic dicent according to Peirce's typology. However, insofar as a 
formal model "shares structural properties" with the object it represents, it functions as an icon. The semiotic duplicity of a sign that is symbol and icon at the same time is discussed in detail below.

Max Black sets up a general typology of models in Chapter XIII of Models and Metaphors (1962) that includes a study of scientific models. According to Black, a common characteristic of models is that they serve the purpose of explaining a domain of less known phenomena in terms of a better-known domain of knowledge. Black proposes the following typology of models, which again emphasizes the features of representation and similarity, hence of the model as an iconic sign:

- Scale models, such as toy model airplanes, are "likenesses of material objects, systems, or processes, whether real or imaginary, that preserve relative proportions" (Black 1962: 220). A scale model can also model an imaginary object. Representation in this case is always asymmetrical: if $A$ is a model of $B$, $B$ is not a model of $A$ (Black 1962: 220). Black (1962: 221) uses Peirce's concept of icon in his definition: "In Peirce's terminology, the [scale] model is an icon, literally embodying the features of interest in the original. It says, as it were, "This is how the original is".

- Analogue models are models in which there is a change of medium, as in "hydraulic models of economic systems or the use of electrical circuits in computers" (Black 1962: 223). The author attributes a more abstract kind of iconicity to analogue models: "The dominating principle of the analogue model is what mathematicians call 'isomorphism' [...] The analogue model shares with its original not a set of features or an identical proportionality of magnitudes but, more abstractly, the same structure or pattern of relationship" (Black 1962: 223).

- Mathematical model is a term that serves "often no more than a pretentious substitute for 'theory' or 'mathematical treatment" (Black 1962: 223); it is just a model formulated in the language of mathematics. Theoretical models are metaphorical systems, creations of secondary domains to explain a betterknown primary domain by analogy. "The use of theoretical models consists in introducing a new language or dialect, suggested by a familiar theory but extended to a new domain of application. [...] Explicit or implicit rules of correlation are available for translating statements about the secondary field into corresponding statements about the original field" (Black 1962: 229-30).

A scale model, such as a model car, a model aircraft, or an architectural model, is an iconic sinsign. A sign of this class "can only be so through its qualities; so that it involves a qualisign, or rather, several qualisigns," says Peirce about them (CP 2.245, 
1903). A scale model may be the representation of a not yet materially existing singular object, such as the model of a planned construction, or the representation of an existing prototype, such as the model car that represents a car model. In the latter case, the sign is "an Iconic Sinsign of a peculiar kind" (CP 2.258, 1903). Analogue models, in which there is a change of medium, consist of icons of a different subclass, which Peirce defines as diagrams. The criteria that come closest to Peirce's criteria of a diagrammatic sign are formulated in Black's expression "same structure or pattern of relationship".

Like Rosenblueth and Wiener's formal model, Black's mathematical model consists of symbols since its signs are formulated in a language, the "language of mathematics", as they call it. Theoretical models, in Black's definition, consist of symbols, too, conventional signs in a specific "language or dialect". Since such models make "statements", which may be true or false, and since all symbols are legisigns, they consist of symbolic dicent legisigns. However, insofar as they are also "metaphorical systems" they incorporate an icon (see Section 2.3 below).

In Models and Metaphors, Mary Hesse (1963) emphasizes the logical affinity between models and metaphors, putting forward the thesis that scientific models are metaphors. Metaphors are the third subtype of icon besides the image and the diagram (see Section 3.1 below), so that Hesse's focus in the study of models is only on a single type of iconicity.

Mario Bunge deals with scientific models in Method, Model and Matter (1973). In his definition, a model is a "hypothetical sketch of supposedly real, though possibly fictitious things or facts” (Bunge 1973: 91). A sketch is a 'rough drawing' and as such is certainly an iconic sign, whether hypothetical or not. When Bunge defines the object domain represented by a model as a "possibly fictitious thing or fact", he defines the object of a sign quite in the sense in which Peirce defined it, when he wrote, "Every sign is regarded as having an object, or real thing to which it corresponds. But though regarded as having an object, it does not cease to be a sign because no such object really exists" (MS 8:4, 1904).

Bunge proposes a typology of models based on the criterion of the medium of representation. Its main types are "pictorial, as in the case of a drawing", "conceptual, as in the case of a mathematical formula", "figurative, like the ball-and spoke model of a molecule", "semisymbolic, as in the case of a contour map of the same molecule; or finally symbolic like the Hamiltonian operator for that same object” (Bunge 1973: 92). All these are descriptions of variants of icons and symbols.

A further distinction drawn by Bunge is between 'model objects' and 'theoretical models' (Bunge 1973: 92). By 'model object', the author means a "schematic representation of a concrete object" (Bunge 1973: 113). From the semiotic perspective, schematic descriptions are diagrams. An object of representation (Bunge calls it 'referent') that is a concrete or physical thing is an 'idealization' (Bunge 1973: 92), whereas a 
'theoretical model' is the expansion of an object model into a full theory, which is a "theory of the model object" (cf. Bunge 1973: 99). More than other writers on the topic, Bunge emphasizes the selective nature of scientific models. Bunge's description is the following:

The representation of a concrete object is always partial and more or less conventional. The model object will miss certain traits of its referent, it is apt to include imaginary elements and will recapture only approximately the relations among the aspects it does incorporate. In particular, most individual variations in class will be deliberately ignored and most of the details of the events involving those individuals will likewise be discarded. (Bunge 1973: 92)

Frigg and Hartmann $(2012)^{3}$ give an encyclopedic account of the notion of model in science in which most of the above-discussed definitions and descriptions of models are included. For them, "A model is a structure [...and] the structure is a 'model' in the sense that it is what the theory represents". A model that represents its object in the form of a structure is a diagrammatic model. The authors distinguish six types of models of which four take up in some way or other the kinds of models described above, namely, scale models, idealized (i.e., simplified) models, analogical models, and phenomenological models (that represent only "observable properties of their target"). The remaining two are fictional objects in the sense of models that only exist "in the scientist's mind rather than in the laboratory" and which "do not have to be physically realized and experimented upon to perform their representational function" (Frigg, Hartmann 2012) and descriptions (in scientific papers and textbooks), but Frigg and Hartmann reject the definition of descriptions as models adopted by some authors.

In the references to the relation between the model and its object domain, two seemingly contradictory features of models recur: simplification and informativity. On the one hand, a model reduces the information conveyed by its original so that it "will miss certain traits of its referent", as Bunge puts it. On the other hand, the model is supposed to be more informative insofar as it is a representation in a domain of knowledge with which we are "more familiar" (Black) or insofar as "it is apt to include imaginary elements" (Bunge 1973: 92).

For Peirce, these are two characteristics of the relation between the sign and its object in general. Any sign abstracts or "prescinds" features (CP 5.449, 1905) from its object since "the sign stands for its object, not in all respects, but in reference to a sort of idea, which I have sometimes called the ground" (CP 2.228, c. 1897). Insofar, the sign conveys less information than can possibly be given about its object. A representation

3 Frigg, Roman; Hartmann, Stephan 2012. Models in science. In: Zalta, Edward N. (ed.), Stanford Encyclopedia of Philosophy (Winter 2016), available at https://plato.stanford.edu/ archives/win2016/entries/models-science/ (accessed Jan. 2017). 
is always incomplete so that the sign can only "endeavor to represent, in part at least, an Object" (CP 6347, c. 1909). Since representation is necessarily incomplete, "no Sign is absolutely precise" and there is always "indefiniteness as to what is the Object of the Sign" (CP 4.543, 1905). The general insight into the necessary loss of information in the process of semiosis is one that Peirce formulated in the following metaphor describing the meaning of a representation as a representation reduced in its content: "The meaning of a representation can be nothing but a representation. In fact, it is nothing but the representation itself conceived as stripped of irrelevant clothing. But this clothing never can be completely stripped off; it is only changed for something more diaphanous" (CP 1.339, 1893-5).

On the other hand, there is the insight that a model conveys additional information about the object it represents, for example, because it shows details not visible to the naked eye. Furthermore, in studying a diagram, we may "discover unnoticed and hidden relations among the parts" (CP 3.363, 1885) and obtain thus new information about the object.

\subsection{Mental models}

The notion of 'mental model' is a key concept in cognitive psychology. Definitions of mental models are rather diverse (Garnham, Oakhill 1996). Only some of them can be examined here from semiotic perspectives. Mental models are internal as opposed to external models. Scientific models are not necessarily mental models, but for a scholar who has internalized a scientific model, this model has become a mental model. What Frigg and Hartmann call a 'fictional model' is a mental model insofar as it exists "in the scientist's mind". The variety of phenomena that cognitive psychologists define as mental models has rather different counterparts in Peirce's semiotics. Some semiotic terms introduced by Peirce come close to the idea of a mental model, others less so. The main reason for the differences is that Peirce's semiotics is not a psychological, but a logical or semiotic theory. A comparison between some examples or types of mental models from the perspective of cognitive psychology can elucidate the similarities and differences.

For Peirce, semiotics is the study not only of external, but also of internal or mental signs. Thoughts are mental signs or mental representations since "we think only in signs", which "are of mixed nature", symbols, icons, and indices (CP 2.302, 1893). With the extension of the scope of semiotics from external signs to mental representations, mental models fall within the scope of the study of signs. The terms that Peirce used with reference to internal signs are mental representations or thought signs, defined as "signs that we think or think through" (CP 4.549, 1906). Verbal thought is thought in symbols, but thought cannot remain restricted to symbols only. It includes mental images and indices that connect the thoughts to experience. A mental image is a 
thought in iconic signs. Let us consider a few examples of mental models as cognitive psychologists define them from the semiotic perspective.

(1) Thought sign. The first type of mental model is one that "represents a state of affairs and accordingly its structure [...] plays a direct representational or analogical role. Its structure mirrors the relevant aspects of the corresponding state of affairs in the world" (Johnson-Laird 1980: 98). Seen from the semiotic perspective, such a mental model must be a symbolic dicentic thought sign since only a dicent can represent a state of affairs and a dicent cannot be an icon. Insofar as it represents a real fact, the thought sign is also indexically connected with its object. Insofar as it represents only "relevant aspects", it shares this characteristic with all models.

(2) Argument. The second type of mental model is exemplified by instances of deductive, inductive, and abductive reasoning based on world knowledge in the following manner, "We construct mental models of each distinct possibility and derive a conclusion from them. [...] Reasoning is a simulation of the world fleshed out with our knowledge, not a formal rearrangement of the logical skeletons of sentences" (Johnson-Laird 2010: 182-43). From the semiotic perspective, such mental models are complex mental signs that Peirce defines as 'arguments'. Arguments are necessarily symbols. The knowledge we need to simulate the world by means of an argumentative model and to draw a valid conclusion cannot be conveyed by the model itself. It is necessarily collateral in the sense that it is a "prerequisite for getting any idea signified by the sign" and that we need to have "previous acquaintance" with it (CP 8.179, c.1903).

(3) Perceptual judgment. The third type of mental model plays its role in acts of perception, "when humans perceive the world, [and] vision yields a mental model of what things are where in the scene in front of them" (Johnson-Laird 2010: 18244). Peirce defines the mental process thus described as the formation of a perceptual judgment, "a mental description of a percept, in language or other symbols” (MS 939: 25: 1905).

(4) Universe of discourse. The fourth way in which the concept of mental model is used can be found in psycholinguistic discourse analysis (Garnham; Oakhill 1996). For example, Graesser et al. (1996: 12) describe a mental model in this context as "a lifelike mental representation of the people, setting, actions, goals, and events that are either explicitly mentioned or inferentially suggested by the text". In Peirce's definition, the totality of such schemata of world knowledge is a "universe of discourse" (CP 2.517, 1893; 2.536, 1902). A universe of discourse comprises the set of all things, persons, facts, or events that can possibly have a truth-value in a textual domain, whether this text be about the actual world of existing objects or about the objects of some fictional or imaginary world, such as the universe of Hamlet's life. 
'Mental model' is not a technical term in Peirce's vocabulary. The Peircean term that comes closest to the one of cognitive psychology is 'mental diagram'. An example is the mental diagram evoked in the process of interpreting the dyad of the two protagonists in the scenario of Cain killing Abel:

The Dyad is a mental Diagram consisting of two images of two objects, one existentially connected with one member of the pair, the other with the other; the one having attached to it, as representing it, a Symbol whose meaning is "First", and the other a Symbol whose meaning is "Second". (CP 2.316, 1903)

Other correspondences between the notion of mental model in cognitive science and Peirce's interpretants can be found in Peircean formulations such as "mental icon" (CP $2.295,2.439$, c. 1893), "image we have in our minds" (CP 1.324, c. 1895), or "mental composite image” (CP 2.440, c. 1893).

\section{Iconic models and the iconicity of models in general}

'Similarity', 'resemblance,' 'likeness', 'analogy', 'isomorphism', or 'pattern' are among the recurrent characteristics in the diverse definitions of scientific models that define models as iconic. The concepts of 'similarity' and of 'the iconic sign' have been criticized for their vagueness. Some have even refused to acknowledge similarity as a useful term in scientific discourse (Eco 1998). For Peirce, by contrast, 'likeness' is not a useless term. In his definition, it is "the natural attraction of ideas apart from habitual outward associations" (MS 787, 26-28; 1897). Signs associated with their object by likeness are icons. Signs that represent their object through "habitual associations" are symbols, and signs that have "outward associations" with their object are indices.

All models involve iconicity, either in the model as a sign, in which case the model is an icon itself, or in its interpretant, but of course, not all icons are models. Pictures, drawings, mirror images, or imitative gestures are icons, but hardly models.

\subsection{Three types of icon and three types of iconic models}

Peirce distinguishes three subtypes of the icon: the image, the diagram, and the metaphor (CP 2.277, 1903). This subdivision can be used for a first typology of iconic models, which distinguishes between image, diagrammatic, and metaphorical models.

(1) Image models. As defined by Peirce, images are icons that "partake of simple qualities" of the object they represent (CP 2.277, 1903). By "quality", Peirce means whatever offers "a possibility of sensation" (CP 1.426, ca. 1896). In 
another definition, the image is an icon "by virtue of characters which belong to it in itself as a sensible object" (CP 4.447, 1903). Such characteristics apply to scale models as well as to a dress presented at a fashion show. When Black (1962: 220) says that a scale model is an "icon, literally embodying the features of interest in the original", he means an icon of the image kind. A scale model shares with its original simple qualities such as colour, material, form and relative proportions. Scale models are hardly scientific models because they merely reduce the size of an object without explaining anything. A semiotic answer to the question why an image cannot serve the purpose of a scientific model can also be found in Peirce's definition of the image as a "pure sign" and qualisign (see below). Such signs belong to the category of the merely possible (Firstness). For this reason, "a pure icon can convey no positive or factual information; for it affords no assurance that there is any such thing in nature" (CP 4.447, 1903).

(2) Diagrams and diagrammatic models. A diagram is an icon that represents some elements of its object and some of the characteristic relations between them (EP 2: 303, 1904). It "represents the relations [...] of the parts of one thing by analogous relations in their own parts" (CP 2.277, 1903). Any model to which these characteristics apply is a diagrammatic model. Peirce's definition of the diagram is very broad. When he speaks of a diagram as "a representamen which is predominantly an icon of relations" (CP 4.418, c. 1903), the term becomes practically synonymous with the concept of 'system'. If systems are diagrams and language is a system, language is fundamentally diagrammatic. Peirce defines the grammatical rules that determine the order of words in a text as an algebra and argues, "All speech is but such an algebra, the repeated signs being the words, which have relations by virtue of the meanings associated with them" (CP 3.418, 1892). When he insists on the diagrammatic nature of language, thought, text, and discourse, it is apparent that he uses the term 'diagram' in the sense in which the structuralists understand the concepts of 'structure' and 'system'.

(3) Metaphorical models. Metaphors are the third type of icon distinguished by Peirce. They do not need to be exemplified here since metaphorical models in science have been studied in a long tradition since the 1960s. Bunge's "figurative" models are metaphorical models, and two of Black's above-quoted general characterizations of models apply in particular to metaphorical models. Metaphorical models also involve mental diagrams because the mental spaces of the sources and targets are conceptual systems, and systems are mental diagrams. 
In Peirce's triadic interpretation, a metaphor is an iconic sign since it "represents the representative character of a representamen by representing a parallelism in something else" (CP 2.277, 1903). Peirce's triad refers to the three mental spaces or domains distinguished by the conceptual theory of metaphor founded by Lakoff and Johnson (1980). First, the mental space of a source domain (of the sign or representamen); second, the one of a target domain (the space of "something else"); and third, a mental space in which both are blended, i.e., a third space in which the "parallelism" between the two is recognized.

Metaphorical models serve to explain a target domain, one with which we are less familiar, in terms of a source domain with which we are more familiar. Both domains are objects of a sign, which is the metaphorical model itself. Black (1962: 223) calls the shift from one domain to the other the "change of medium". A metaphorical model is a theoretical model if it consists of a coherent system of metaphors representing a complex domain of phenomena. Such models abound in all sciences. The vocabulary of electrical engineering, with its metaphors of electricity as a fluid that flows in a current against resistances and where bridges can be found, may suffice as an example. The mental image of flowing water is the source domain that serves to explain the less well understood electrical process.

Mark Johnson (1981: 42) affirms, "that science cannot do without metaphor [and] that all theories are elaborations of basic metaphors or systems of metaphors", and in Physics as Metaphor, Jones (1982) has argued that metaphorical models are so prominent in physics that they are not only a rhetorical tool but a necessity for the presentation of any research result in physics.

\subsection{On the iconicity of models in general}

Above, we saw that a model is not necessarily a graphic representation but may have the form of a complex verbal symbol, such as a metaphor, that evokes a mental image (see Section 1.4 above). Peirce extends this line of argument from verbal to mathematical symbols. For him, a mathematical equation is an icon. Not only every picture is an icon, but also every diagram is, even without any "sensuous resemblance" to its object. Instead, the relation of iconicity between sign and object is one of an analogy. About the iconicity of mathematical formula, Peirce goes on to say, "Particularly deserving of notice are icons in which the likeness is aided by conventional rules. Thus, an algebraic formula is an icon, rendered such by the rules of commutation, association, and distribution of the symbols [...]. For a great distinguishing property of the icon is that by the direct observation of it other truths concerning its object can be discovered than those which suffice to determine its construction" (CP 2.279, c.1902). Now, if 
mathematical formula are icons in this sense, those models that have been defined as formal, symbolic, or theoretical (see Section 1.4) are iconic, too. However, the iconicity inherent in these models differs from the iconicity of graphical diagrams. When Peirce writes that a "mathematical truth is derived from observation of creations of our own visual imagination, which we may set down on paper in form of diagrams" (CP 2.77, 1902), he does not describe an iconic sign, but the interpretant of a symbolic sign. While the sign has the form of a symbol, its interpretant is an icon. In a comment on the iconicity of a mathematical formula that formulates a law of optics, Peirce writes:

For example, let $f[1]$ and $f[2]$ be the two distances of the two foci of a lens from the lens. Then, $1 / f[1]+1 / f[2]=1 / f[0] .{ }^{4}$ This equation is a diagram of the form of the relation between the two focal distances and the principal focal distance; and the conventions of algebra (and all diagrams, nay all pictures, depend upon conventions) in conjunction with the writing of the equation, establish a relation between the very letters $f[1], f[2], f[0]$ regardless of their significance, the form of which relation is the Very Same as the form of the relation between the three focal distances that these letters denote. (CP 4.530, 1906)

The example illustrates how a mathematical equation, which is a formal model of the distances of objects and images from a thin lens, becomes a mental diagram in its interpretant, which interprets the symbol as an icon of the form of the relations of equivalence between these distances. To understand how symbolic signs become icons in their interpretants, it is particularly illuminating what Peirce says about arguments. Considered as a sign, "the Argument must be a Symbol. As a Symbol it must, further, be a Legisign," says Peirce (CP 2.263, 1903). However, the interpretant of an argument has the form of a mental diagram since deductive reasoning "consists in constructing an image or diagram in accordance with a general precept, in observing in that image certain relations of parts not explicitly laid down in the precept, and in convincing oneself that the same relations will always occur when that precept is followed out" (CP 8.209, c. 1905).

Why is the interpretant not of the same sign class as the sign that it interprets? A symbol represents its object merely because the interpreter has the habit of doing so (cf. EP 2: 461, 1909), and this habit is the embodiment of a mental law or a rule (cf. CP $1.536,1903)$ too abstract to be interpretable. The symbol alone cannot connect the sign to an object of experience and convey significance to it (cf. Santaella Braga 2003: 47). Reference to objects, whether external or mental, requires an index, and any significance can only attributed to it by means of icons. Peirce describes how a

4 For this so-called thin lens equation that formulates the relation between object distance, image distance, and focal length, see http://hyperphysics.phy-astr.gsu.edu/hbase/geoopt/ lenseq.html. Accessed March 2018. 
symbol, such as a common noun, requires icons and indices to become intelligible in an interpretant as follows:

Any Symbol is necessarily itself of the nature of a general type, and is thus a Legisign. [...]. Its Replica draws attention to a single Object, and is a Rhematic Indexical Sinsign. A Replica of the word "camel" is likewise a Rhematic Indexical Sinsign, being really affected, through the knowledge of camels, common to the speaker and auditor, by the real camel it denotes, even if this one is not individually known to the auditor; and it is through such real connection that the word "camel" calls up the idea of a camel. [...] Replicas of Rhematic Symbols very different from ordinary Rhematic Indexical Sinsigns [...] The Interpretant of the Rhematic Symbol often represents it as a Rhematic Indexical Legisign; at other times as an Iconic Legisign; and it does in a small measure partake of the nature of both. (CP $2.261,1903)$

The distinction between the symbol as a legisign and as a replica accounts for the difference between the symbol as an abstract general rule without any embodiment and its embodied use in a given instance. Only the latter, the symbol as conveyed from a speaker to a hearer, is interpreted. In the process of interpretation, it is connected indexically to the hearer's knowledge horizon so that it becomes an index qua interpretant. The attributes that the hearer is able to associate with the object of reference are icons, predicates that describe what the object is like. Insofar as the conjunction of the subject and the predicate define what a camel is in general, it is a legisign.

\subsection{Why iconic models need indices and symbols to make them informative}

Diagrammatic models are hybrid signs insofar as they are icons but contain indices and symbols, too. Peirce considers this hybridity when he defines a diagram as a "predominantly" iconic sign and specifies that it is "aided to be a diagram by conventions" (i.e., by symbols) and that "indices are also more or less used" (CP 4.418, 1903). For Peirce, the iconic constituent of a model is the predicate of a proposition, when he states, "A diagram is an icon or schematic image embodying the meaning of a general predicate" (EP 2: 303, 1904). The subject part necessary to complete the proposition is of the nature of an index. In the case of a map, the index is the name (the toponym) of the territory it represents. Proper names including toponyms are generally indices, not only on maps, because they indicate singular places or persons. Unlike symbols, they have no general meanings. A map usually indicates many places, each of them by a toponym, say X, that informs its readers, "Here is X". The diagram then adds, so to speak, "and X has my shape". Symbols used on a map, such as 'Church' or 'Bus stop' are indices in their interpretant. Their information is, "Here is a church". In addition, many diagrams contain internal indices in the form of arrows 
or simply connecting lines. Their indexicality serves merely to visualize the relation of indexicality between the name and its iconic representation.

In addition, a diagram needs indices that connect it to the interpreters' collateral experience of objects in the external world. The sign alone cannot convey this knowledge. Collateral experience that needs to be acquired independently of the sign can convey this knowledge (CP 8.178, 1909). Peirce calls this necessary experience that must precede the understanding of any sign "collateral experience" or "collateral information" about, or "collateral acquaintance" with, the object of the sign (e.g., CP $6.338,1908)$. Without collateral knowledge, a sign remains unintelligible since only real-life experience "can teach its interpreter" what it means (CP 8.178, 1903).

Peirce often compares the semiotic potential of icons to the ones of indices and symbols. An index can only indicate its object, with which we must already be familiar independently of the index. Hence, it cannot convey any information about it. Symbols alone cannot convey new information either since they are signs determined only by habits (cf. Nöth 2010). Pure icons are too vague. They represent mere possibilities. Without an index, they remain unconnected with the world of existing facts. Pictures that have a real connection to existing facts have it by various types of indices connected with them, such as mental indices that our memory provides to connect them with scenes once observed. This is why iconic models are necessarily hybrid signs. Without indices and symbols make the icon intelligible, the model remains uninformative. Consider the diagram in Fig. 1, a typical model from the science of biology (Stahl 2015).

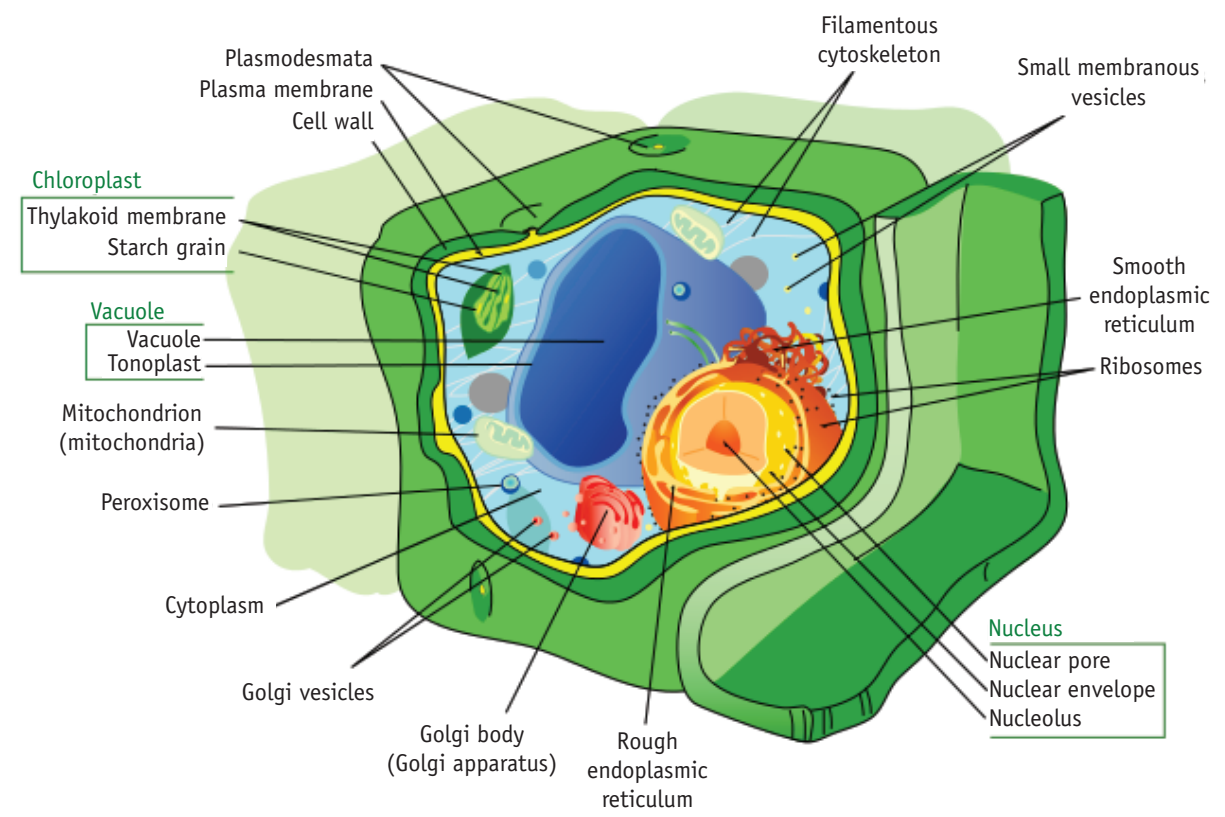

Figure 1. Diagrammatic model of a plant cell (goo.gl/6stq7O, accessed Sept 2017). 
Fig. 1 illustrates how a diagrammatic model becomes informative through the symbols and indices incorporated in it. If we take away the words and the connecting lines and consider only the graphic representation, we can see how the remaining diagram is uninformative. We only have the information that something looks like this, but do not know what. About such a pure icon, Peirce says, it "cannot of itself convey any information, being applicable to everything or to nothing" (CP 3.433, 1894). Alone, a diagram is only a sign of possible, not of real, qualities and relations.

The terms that designate the various components of the cell are symbols, that is, "Signs which represent, to those that can interpret them, the objects they do [...] solely because those interpreters have habits of mind [...] that lead them whenever they perceive the signs straightway to think of those Objects" (MS 638: 20-21, 1909). However, in their interpretants, these symbols become indices because they constitute the subject part of a semiverbal proposition whose predicate part is the icon that represents what the respective component looks like. The information the term conveys in conjunction with the picture of the object it designates is, for example, "The nucleus is here, and it looks like this: -". The lines that connect the anatomical terms with the diverse loci in the diagram are additional indices, i.e., signs that represent their objects "only by virtue of real connections with them" (EP 2: 460-461, 1909). They convey no information of their own since an "index asserts nothing; it only says 'There!' It takes hold of our eyes, as it were, and forcibly directs them to a particular object, and there it stops" (W 5: 162-3, 1885).

For example, a line connects the symbol 'Cytoplasm' with the image of cytoplasm to represent a proposition-like sign - Peirce defines it as a dicent -, whose meaning can be paraphrased as "Cytoplasm looks like this.... The pointer 'this', in the form of the line, connects the term with the iconic representation of cytoplasm. This nonverbal diagrammatic proposition has the symbol 'Cytoplasm' as its subject and the image of cytoplasm as its predicate. The index of the line represents a syntactic structure; it connects the subject with the predicate.

The model also makes use of other diagrammatic devices. For example, the square bracket below the word 'Nucleus', both printed in green, which encloses the terms 'Nuclear pore, Nuclear envelope, Nucleolus', printed in black, is a diagram representing the relationship of subordination, showing that the three concepts printed in black and included within the green boxlike bracket are subordinate terms of the superordinate term 'Nucleus'.

So far, the focus of our semiotic analysis of the plant cell model has been on how symbols, indices, and icons combine into one complex sign. Through its fifteen dicents, each of which combines a symbol (the anatomical term) with an icon of the image class, the model informs about what the components of a plant cell look like and what they are called. Now, the purpose of the model is to give information about 
plant cells in general, not only about some singular cell. Generality is a distinctive feature of symbols. How then should the complex graphic representation be classified as a sign? Is it predominantly a symbol or a diagram?

About the generality that characterizes a symbol, Peirce writes, "The denotation of a symbol is always definitely general, that is, it stands for any object its interpreter may choose" (MS 842: 34, 1908). Here we have a pragmatic definition of a symbol that is applied to models, too. Any interpreter may choose any plant cell and will find that the chosen cell has the structure represented by the model. However, generality is also a characteristic of diagrams that do not represent a singular object. Peirce refers to the generality of such diagrams when he writes:

A Diagram [...] is, however, what is called a General sign; that is, it denotes a general Object. It is, indeed, constructed with that intention, and thus represents the Object of that intention. Now the Object of an intention, purpose, or desire is always General. The Diagram represents a definite Form of Relation. This Relation is usually one which actually exists, as in a map, or is intended to exist, as in a Plan. But this is so far from being essential to the Diagram as such, that if details are added to represented existential or experiential peculiarities, such additions are distinctly of an undiagrammatic nature. (NEM 4: 315-316n, 1906)

According to these premises, the model in Fig. 1 is a general sign of the diagram class. The index that connects it to really existing plant cells is not one of its essential characteristics and the symbols that it contains are not essential to the kind of sign it is, either. Symbols also represent general ideas, but unlike diagrams, which can show what something looks like, symbols cannot show anything, and therefore, they cannot create new knowledge, argues Peirce:

Symbols enable us, for example, to create Abstractions, without which we should lack a great engine of discovery. [...] In many respects, they are the very warp of reason. But since symbols rest exclusively on habits already definitely formed but not furnishing any observation even of themselves, and since knowledge is habit, they do not enable us to add to our knowledge even so much as a necessary consequent, unless by means of a definite preformed habit. (CP 4.531, 1906)

In their mix of the iconic with the indexical and the symbolic, diagrams are omnipresent in mathematics, logic, language, rational thought in general, and texts of any kind (cf. Stjernfelt 2007). Although they are predominantly diagrams, as shown above, models such as the one of Fig. 1 are not "pure diagrams". Pure diagrams are signs "designed to represent and to render intelligible, the Form of Relation merely" and are hence "restricted to the representation of a certain class of relations; namely, those that are intelligible" (NEM 4: 316, fn.). Diagrams as used in models, by contrast, are only 
part of a more complex sign, in the context of which they serve to illustrate features of an object represented by another sign, usually specified in the caption of the diagram. In our case, this second sign is the symbol "plant cell". Both signs together are in a subject-predicate relation. The symbol "plant cell" is the subject and the diagram, which shows what a plant cell looks like, is the predicate part of this complex sign. About the predicative character of a diagram, Peirce writes, "A diagram is an icon or schematic image embodying the meaning of a general predicate; and from the observation of this icon we are supposed to construct a new general predicate" (EP 2: $303,1904)$.

\subsection{The iconicity of scientific models revisited}

Philosophers of science concerned with the nature of scientific models have shown considerable disagreement as to the iconicity of models. Some have attributed iconicity to models in general by defining them as metaphors or diagrams. Others have introduced terms such as 'theoretical', 'formal', or 'symbolic model', which suggest that only some models are iconic, whereas others are not (see Section 1.4). For still others, iconicity is not a distinguishing criterion of the typology of models. Peirce's theory of iconicity sheds a different light on the issue. A review of the divergent views concerning the iconicity of models may therefore be appropriate and useful in summary.

For Rosenblueth and Wiener (see Section 2.1), a formal model is not only "a symbolic assertion" and hence a symbol. The authors also attribute iconicity to formal models by defining them as models that "share the structural properties of the original factual system" (Rosenblueth, Wiener 1945: 317). Mihram and Mihram (1974: 42-43) draw on Rosenblueth and Wiener's dichotomy of material and formal models, but rename the former as 'physical' and the latter as 'symbolic' models. These authors subdivide physical models into (1) 'replicas', such as "biological twins and earthen relief maps"; (2) 'quasi-replicas', such as "silhouettes and planetarium shows"; and (3) analogues, such as statues. Symbolic models are subdivided into descriptions, simulations, and formalizations.

Black's views concerning the iconic essence of models were still somewhat ambiguous in 1962. On the one hand, he emphasized the difference between models and metaphors, which consisted, in his assessment, in that models evince some "objective iconicity" (Black 1962: 238) in relation to their original, whereas metaphors "operate largely with commonplace implications" (Black 1962: 239; cf. Haley 1988: 55). On the other hand, he wrote that the "use of theoretical models resembles the use of metaphors in requiring analogical transfer of vocabulary. Metaphor and model-making reveal new relationships; both are attempts to pour new content into old bottles" (Black 1962: 238239). In 1977, Black saw it differently: "I am now impressed, as I was insufficiently so 
when composing Metaphor, by the tight connections between the notions of models and metaphors. Every implication-complex supported by a metaphor's secondary subject, I now think, is a model of the ascriptions imputed to the primary subject: Every metaphor is the tip of a submerged model" (Black 1977: 31). When Black discussed models as metaphors, he did not mean visual, but verbal metaphors, i.e., metaphors formulated in the form of words, the prototype of symbolic signs.

Other authors discuss "theoretical models" as exclusively or at least predominantly symbolic. Achinstein (1965: 103) distinguishes between iconic and theoretical models as follows: "A theoretical model consists of a set of assumptions about some object or system. [...] Theoretical models must be distinguished from diagrams, pictures, or physical constructions which, though sometimes useful in presenting the model, are not to be identified as the model itself". Nagel (1961: 90) characterizes a theoretical model as consisting of "a set of true propositions", which means that these models must consist of symbolic signs. Zeidler (2013: 66) interprets theoretical models as "symbolic" in a semiotic definition of the term. However, there are also others, who interpret theoretical models as variants of iconic models, attributing iconicity to all types of models. Icons include analogies, diagrams, and metaphors. Should diagrammatic, analogical, and metaphorical models therefore not be included within the general class of icons?

\subsection{Symbolic models: Symbolic signs with iconic interpretants}

Peirce's distinction between the sign and its interpretant offers a solution to the problem of how to interpret models formulated in words and hence symbols, but in which verbal analogies, parallelisms, and metaphors are predominant, as in the example of Adam Smith's model of the economy. As a sign, a model formulated entirely in verbal language is a complex symbol of the class of the argument, but the metaphors and analogies that such complex symbols contain are icons in their interpretants. The interpretant of a sign is the effect of a sign on an interpreter, such as the "idea which it produces" in an interpreter (CP 1.339, 1893-5). The interpretant of a theoretical model is a hybrid mental sign that consists of symbols, indices, and icons. The interpretants of analogies and metaphors consist of the mental images they evoke, and these are icons.

In the case of a model that is iconic qua sign, the interpretant will be an icon, too, since the interpretant is an iconic mental representation of the sign. In the case of a theoretical model formulated in verbal signs, the sign is a symbol, but its interpretant contains icons in the form of the mental images it evokes. Peirce defines such semiotic duplicities of signs and their interpretants as cases of "signs overlying signs": 
In consequence of every sign determining an Interpretant, which is itself a sign, we have sign overlying sign. The consequence of this, in its turn, is that a sign may, in its immediate exterior, be of one of the three classes, [i.e., icon, index, or symbol, W. N.] but may at once determine a sign of another class. But this in its turn determines a sign whose character has to be considered. This subject has to be carefully considered, and order brought into the relations of the strata of signs, if I may call them so, before what follows can be made clear. (CP 2.94, c. 1902)

Hence, the iconicity of symbolic models is a matter of their interpretants, which may be mental images, diagrams or the images implied in metaphors. Even in rational discourse, the interpretant requires icons, mainly diagrams. To interpret an argument is to form a mental diagram of the relations between the premises and the conclusion. Reasoning means thus forming mental diagrams as interpretants of symbolic signs. Peirce puts it as follows, "Remember it is by icons only that we really reason, and abstract statements are valueless in reasoning except so far as they aid us to construct diagrams" (CP 4.127, 1893). Diagrammatic reasoning begins with the interpretation of ordinary syntactic structure:

The arrangement of the words in the sentence, for instance, must serve as Icons, in order that the sentence may be understood. The chief need for the Icons is in order to show the Forms of the synthesis of the elements of thought. For in precision of speech, Icons can represent nothing but Forms and Feelings. That is why Diagrams are indispensable in all Mathematics, from Vulgar Arithmetic up, and in Logic are almost so. For Reasoning, nay, Logic generally, hinges entirely on Forms. (CP 4.544, 1905)

The diagrams by which linguists represent syntactic structures are models of the mental diagrams, which are the interpretants of sentences. Mathematical equations are further examples of symbolic signs whose interpretants involve mental diagrams, which represent the relations between elements.

\section{Models as types (legisigns)}

The concept of a model as a type in the sense of a pattern for replicas was introduced in Section 1.3. Tchertov (2015: 78) subdivides such models further into models as patterns for reproduction, such as a model town or the most recent car model, and models in the sense of objects reproducing a model, such as a toy car. Although toy cars are occasionally called 'models' tout court in ordinary language, they do not serve as models for anything. Instead, they are miniature replicas of a car model that is or was the type of a certain model year. One of the philosophers of science who paid attention 
to the model as a type and the fact that tokens are the product of such types is Rom Harré. While adopting the type-token distinction from Peirce's first trichotomy, Harré (2004: 4) writes in an article entitled "Iconic models":

Then there is the use of the word 'model' to designate a type. A new version of a car is a 'new model'. Sometimes this slides over, in careless talk, into reference to the token as a token representative of the type. In such expressions as 'I bought this year's model' where I mean to indicate that I bought one of this year's type.

\subsection{Models as legisigns, sinsigns, and their embodiments in replicas}

The study of models as types pertains to the first trichotomy of signs introduced above, which distinguishes between qualisigns, sinsigns, and legisigns (see Section 1.5) from which we already excluded qualisigns as a possible class. A qualisign cannot be a model although all models incorporate qualities that constitute them as signs so that they do contain qualisigns. In the remaining list of five possible semiotic classes of models, four are legisigns and one is a sinsign. Above, we considered how models serve as types that determine replicas of itself. Are all models types in this sense or can models also serve as sinsigns? We only need to examine this question with respect to iconic and symbolic legisigns since indexical legisigns cannot be models.

Peirce defines the legisign as a "general type which is significant because it may be embodied in instances which have noticeable relations adapting them to be signs of the very objects denoted" (MS 284: 59, 1905). A symbol is the prototype of a legisign because it acts as a rule, a semiotic law, but there are also indexical legisigns and iconic legisigns. The former need not be considered here; the latter remain to be examined.

The study of legisigns has two facets, the one of the legisign as a law and the one of its replicas or embodiments. As a law, a legisign has no material existence. Notice that the relationship between type and token is not the one between a class and its members. A car model in the sense of a type does not only determine the cars produced after its design, but also those cars that have not yet been produced. The law determines its real and its possible embodiments in its replicas. However, in its embodied form, a type is no longer a legisign since the replica of a legisign is a sinsign. The diagrammatic model of a plant cell in Fig. 1 exemplifies the dual nature of a legisign embodied in a sinsign. The diagram is a legisign or type insofar as it is meant to represent a plant cell in general, but the reader's copy in print of this legisign as well as his or her mental processing of it is a sinsign or replica, in the sense in which any occurrence of a general type in a particular instance is a replica (cf. CP 8.335, 1904).

In a special sense, all replicas are icons of their type since they are necessarily similar to their type. "Being a Legisign, its mode of being is that of governing single Replicas, each of which will be an Iconic Sinsign of a peculiar kind" (CP 2.258, 1903). 
In another special sense, all replicas of legisigns are sinsigns since they are singular objects. The article 'the', considered as a word of the English language, is a symbolic legisign, but the utterance of the word in a single sentence is a sinsign. However, when we look at Peirce's ten classes of signs, we find that there is none called 'symbolic sinsign'. Peirce explains the absence of such a class among his ten classes when he mentions that the replicas of symbols are only sinsigns in a special sense:

The word "the" will usually occur from fifteen to twenty-five times on a page. It is in all these occurrences one and the same word, the same legisign. Each single instance of it is a Replica. The Replica is a Sinsign. Thus, every Legisign requires Sinsigns. But these are not ordinary Sinsigns, such as are peculiar occurrences that are regarded as significant. Nor would the Replica be significant if it were not for the law which renders it so. (CP 2.246, 1903)

In contrast to the symbols, of which he classifies none as a sinsign among his ten classes, Peirce distinguishes two subclasses of icons according to the first trichotomy (see Section 1.5). One is the iconic sinsign (class II), the other the iconic legisign (class V). Peirce's comments concerning the differences between the two are scarce:

An Iconic Sinsign [e.g., an individual diagram] is [...] a sign by likeness purely, of whatever it may be like. (CP 2.255, 1903)

An Iconic Legisign [e.g., a diagram, apart from its factual individuality] is any general law or type, in so far as it requires each instance of it to embody a definite quality which renders it fit to call up in the mind the idea of a like object. (CP $2.258,1903$ )

More differences between iconic sinsigns and iconic legisigns can be derived from the definitions of legisigns and sinsigns in general, e.g., "A Legisign is a law that is a Sign. This law is usually established by men. Every conventional sign is a legisign [but not conversely]. It is not a single object, but a general type which, it has been agreed, shall be significant" (CP 2. 246, 1903).

Hence, icons are legisigns or types when they are adopted as such by a convention. Examples are the international Olympic logotypes for the various sports, such as fencing, boxing, or swimming, as well as iconic traffic signs, such as the one for bikeways. Examples of diagrammatic legisigns are maps of railway networks, the iconographic trinity triangle, or the diagram of a circle by which a teacher illustrates the idea of a circle in general. The decisive feature of an iconic legisign is its embodiment in replicas: "Every legisign signifies through an instance of its application, which may be termed a Replica of it" (CP 2. 246, 1903). As such, the replicas or a legisign are sinsigns, but only "of a peculiar kind", as in the case of the replicas of symbolic legisigns. 
As in the case of the classification of symbols, Peirce's classification of iconic sinsigns (II) does not include the replicas of legisigns. It only classifies genuinely singular icons in the sense of signs that are "actual existent things" (CP 2.245, 1903) without being replicas of types. Nathan Houser applies this typology of iconic signs in his "Peircean classification of models", and distinguishes two classes of iconic models as follows:

Models that are Rhematic Iconic Sinsigns are essentially actual (existing) things or occurrences - such as objects or events. They represent, or model, particular objects or events by being sufficiently like them. An architect's drawing models the very house you may soon live in, and a highway sign that depicts a bounding deer models a (possible) event you should prepare for.

Models that are Rhematic Iconic Legisigns are essentially general and lawlike and represent, or model, by exhibiting a type that all instances must embody or conform to. Thus, geometric figures drawn on a blackboard model the shapes they roughly embody, and which all instances of those shapes must embody, and an algebraic formula models the relation it expresses. (Houser 1991: 434)

We may leave it open whether a highway sign and an architectural drawing are models at all although they are not technically called so, but a three-dimensional architectural model is certainly a typical example of a scale model as it is included in Max Black's typology of models (see Section 2.1). A scale model is a singular sign even though it may be copied and replicated itself, but it is not necessarily meant to be so. An architectural model is meant to represent an individual building, which is a mental sign as long as it is not yet constructed.

\subsection{Models as rhemes, dicents, or arguments}

In our list of possible semiotic classes of models (see Section 1.5) the cases not yet examined concern the third trichotomy, which distinguishes between signs as rhemes, dicents, and arguments. For symbolic models, this trichotomy is fully applicable. A symbolic rhematic model is less typical of models in general, but there are examples deriving from the linguistic study of analogy in word formation, where existing words become the model from which new words are derived. Metaphors may also be mentioned as examples of borrowings from other contexts to serve as models for the description of certain innovative products, as in the case of the computer "mouse".

Dicentic symbolic models can be found among the mental or conceptual models. Richard Dawkins's 'memes' that are said to replicate themselves in the minds of members of cultures or social groups have mainly a propositional form. When Rosenblueth and Wiener define formal models as 'assertions' (see Section 2.1), they attribute a propositional structure to them. 
Among the scientific models of the symbolic kind, the main class is certainly that of the model that develops an argument. The class of the argument is not restricted to the one of syllogisms. In 1908, Peirce defines an argument in the much broader sense of "any process of thought reasonably tending to produce a definite belief" (CP 6.456). Thus defined, Adam Smith's above-quoted symbolic model of the economy as a machine in which an invisible hand is at work can certainly be classified as a model of the class of arguments.

For the classification of iconic models from the perspective of the third trichotomy, Peirce offers only one option, the subclass of the rheme. Why can an icon not be a dicent or an argument? The answer to this question is in Peirce's definition of the rheme (or rhema) as the predicate part of a proposition. Accordingly, a rheme is "that which remains of a Proposition after removal of its Subject". "It is conceived to be a part, the predicate of that proposition" (CP 4.438, c. 1903). This conception means that a rheme alone has no truth-value. It is a sign of something that is a mere possibility because the possibility has not yet become actualized by a subject. The subject part of a proposition, by contrast, is its index part. A dicent hence combines an icon with an index. Only the latter can connect the dicent with the universe of discourse in which it is true or not.

When Hutten (1953: 296) writes that "a model may or may not be suitable; it always has its limitations; but it is not either true or false, or confirmable, or directly subject to what is usually called induction", he can only mean one semiotic type of model, which is the iconic rheme. Hutten's argument is that iconic models cannot be dicents nor arguments. If iconic rhemes, whether diagrams or not, are only predicates, they cannot be true or false alone. Mere predicates are uninformative, too, since they assert nothing. Only in combination with indices can they convey information. When we consider diagrammatic models as informative, we consider not only their iconic part, but also their indexical part, which establishes the connection with the reality they refer to. Consider the example in Fig. 1. Does not the model of the plant cell affirm that the structure of such a cell and the arrangements of the elements is the one shown in the diagram, and is it therefore not a dicent instead of a mere rheme? It does so, but only in conjunction with the words and indices that make it informative.

\subsection{Lotman's modelling systems as an iconic type}

'Model', 'modelling' and 'modelling system' are key concepts of Juri Lotman's semiotics of language and culture. Lotman begins with a very broad definition of the concept of model and continues to define 'modelling activity' and 'modelling system' as further key concepts of his cultural semiotics: 
1.2.1. From the multitude of definitions of model, the most general one will be used here: a model is an analogue of an object of perception that substitutes it in the process of perception. [...]

1.3.0. Modelling activity is human activity in creating models. In order that the results of this activity could be taken as analogues of an object, they have to obey certain (intuitively or consciously established) rules of analogy and, therefore, be related to one modelling system or another.

1.3.1. A modelling system is a structure of elements and rules of their combination, existing in a state of fixed analogy to the whole sphere of the object of perception, cognition, or organization. For this reason, a modeling system may be treated as a language.

1.4. It is useful to call those systems that have natural language as their basis and accumulate additional superstructures, thus creating second order languages, secondary modelling systems. (Lotman 2011[1967]: 250, emphases in the original)

When Lotman calls a modelling system a "language" and a "structure of elements and rules of their combination", he conceives models as types in the above-defined sense. The embodiment of a modelling system in a text would thus be a token of such a type. Thomas A. Sebeok describes the duality of the Moscow-Tartu School's conception of semiotic modelling in terms of the dichotomy of a program and its actualization:

A model of the world thus constitutes a program for the behavior of the individual, the collectivity, the machine, etc., since it defines its choice of operations, as well as the rules and motivations underlying them. A model of the world can be actualized in the various forms of human behavior and its products, including linguistic texts - hence the emphasis of the verbal arts - social institutions, movements of civilization, and so forth. (Sebeok 1991: 327)

Lotman's initial definition of a model as "an analogue of an object of perception that substitutes it in the process of perception" and the subsequent recurrence of the notions of analogue and analogy suggest that models are iconic signs. Lotman says this explicitly, while also introducing a distinction between sign and model, in the following:

A model differs from a sign as such in that it not only substitutes a certain denotatum, but substitutes it productively in the process of perception or organization of an object. In that case, if the relation between language and denotatum in a natural language is historico-conventional, then the relation between model and an object is determined by the structure of the modelling system. In this sense, only one type of signs - iconical signs - can be equated to models. (Lotman 1967: 251) 
A primary modelling system, such as a natural language, is iconic insofar as it is in "a state of fixed analogy to the whole sphere of the object of perception, cognition, or organization". Secondary modelling systems, by contrast, have a natural language as their basis, and add "additional superstructures", thus creating languages of a second level. Such semiotic systems are created in mythological, religious, legal, ideological, or literary texts, written in the language of the primary modelling system. The great emphasis he attributes to metaphors in secondary models gives iconicity in these systems an extra prominence (see Nöth 2006).

Lotman's definition of language as an iconic modelling system is not incompatible with Peirce's view of language as a mental diagram. Both views of language postulate iconic correspondences between language and their objects of reference. Whereas Lotman puts emphasis on structural patterns of fixed correspondences (which are diagrams), Peirce assumes, instead, a "living" form of correspondence between concepts and their objects of reference:

A concept is the living influence upon us of a diagram, or icon, with whose several parts are connected in thought an equal number of feelings or ideas. The law of mind is that feelings and ideas attach themselves in thought so as to form systems. But the icon is not always clearly apprehended. (CP 7.467, 1893)

\section{The rhetoric of models}

In the history of the philosophy of science, scholars have not always acknowledged that models are useful tools in scientific discourse. Some have even frowned upon them for allegedly diminishing the rationality of the arguments, but today the rhetorical qualities of models in scientific discourse are out of question.

\subsection{The scientific prestige of mental models}

The distinction between material and mental models, also discussed under the designations of external and internal models (Tchertov 2015: 79), has become rather well established in the philosophy of science and in cognitive science since the 1980s (Johnson-Laird 1983; Garnham, Oakhill 1996). However, in the positivist and behaviourist traditions until the 1970s, before the rise of cognitive psychology and philosophy, the idea of mental or internal models used to be frowned upon. None of the classics discussed above who wrote on models in the philosophy of science before the 1970s included internal or mental models in their studies. Frigg and Hartmann, in their account of the state of the art in model theory in the philosophy of science, report that Quine (1953) and other logicians of his time were skeptical about the scientific 
value of notions such as 'internal', 'mental', or 'fictional' models. Their criticism was based on ontological doubts: "Fictional entities are notoriously beset with ontological riddles, $[\ldots]$ there are no such things as fictional entities, and apparent ontological commitments to them must be renounced" (Frigg, Hartmann 2012).

Peirce anticipated the cognitive turn away from the restriction to studies in external signs and models towards the acknowledgement of the reality of internal ones, when he included in his definition of signs what he called "thought signs" (CP 5.283-86, 1868). The concept postulates that ideas, mental images, and mental models are signs, too. In his advanced semiotic theory, Peirce also offers objections against the positivist and behaviourist argument that only external signs should be the object of scientific investigation. His argument was that internal signs are no less real than external ones. Only their mode of reality differs. External signs belong to the Reality of Secondness, which is the sphere of objects existing materially in time and space. Material models as well as formal and theoretical models in their physical embodiment belong to this sphere of reality.

Internal signs, by contrast, belong to "The Reality of Thirdness" (CP 5.93-5.129, 1903). Mental models and other internal signs are no less real because they exert a "real influence" on the thoughts, plans, and actions of their interpreters. The reality of legisigns is not a reality of Secondness, although legisigns are embodied in this reality as sinsigns. In support of the argument that all signs and hence all models, whether material, mental, or fictional, are real, Peirce argues as follows: "The [legi] sign is not a real thing. It is of such a nature as to exist in replicas. Look down a printed page, and every the you see is the same word, every $e$ the same letter. A real thing does not so exist in replica. The being of a sign is merely being represented" (EP 2: 303, 1904).

Peirce radicalizes this theory of the Reality of Thirdness in contrast to its embodiment in singular instances when he concludes, "That thoughts act on the physical world and conversely, is one of the most familiar of facts [... and] those who deny it are persons with whom theories are stronger than facts" (CP 5.106, 1903). In sum, the ontological difference between external and internal models in this perspective is that the former exist in time and space, whereas the latter are thought signs and more generally types even if they are not embodied in thoughts.

The terms 'thought sign' and 'mental model' suggest that Peirce's Reality of Thirdness is a psychological reality, but more precisely, Peirce's Reality of Thirdness is not a psychological, but a semiotic reality. In this sense, the reality of internal models does not only consist in their cognitive effects; it consists rather in its semiotic (which, for Peirce, is a synonym of 'logical') stringency and consequences. Peirce's alternative term for 'type', 'legisign', makes clear that models are semiotic laws, which do have material embodiments in physical representations but have a reality of their own even without such embodiments. This reality is the one of semiotic laws. 
From the perspective of 20th-century semiotics, it is worthwhile noting that Peirce was not the only one to extend the notion of sign beyond the external sign and thus to lay the foundation for a semiotic theory of internal models. Ferdinand de Saussure, the founder of structural semiotics, also conceived of the sign as something that is not in its essence a physical or physiological thing. His model of the verbal sign as the union of a signified, concept or idea with a signifier in the form of the so-called "sound image" (Saussure 1969[1916]: 67) is a mental model. The difference between Saussure and Peirce in this respect is that the former considered the reality of signs as one of the laws of social psychology (Saussure 1969[1916]: 6), whereas the latter postulated laws of a semiotic reality independent of social or psychological factors.

It is true that the embodiment of the sign is materially necessary for communication, the propagation of ideas, and the growth of signs, but materiality is not a necessary condition for a sign to be a sign. A sign is a sign qua its semiotic potential, its agency is the one of a would-be. This is why mental models are genuine signs and not merely the mental correlates of their externalizations. What is true of signs in general is equally true of models in particular. Models cannot be reduced to twoor three-dimensional representation; mental and logical models are models in their own right, not merely the invisible correlates of their externalizations on paper or on the computer screen. The essence of a model is its interpretability. Considered as legisigns, models are laws, but a "law never can be embodied in its character as a law except by determining a habit” (CP 1.536, 1903).

\subsection{Arguments against and for iconicity in scientific discourse}

Some scholars have opposed iconic and symbolic models sharply or have even suggested that symbols are superior to icons in scientific discourse. Mario Bunge was one of them, when he discussed the iconic elements of quantum theory under the heading "Analogy in quantum theory: From insight to nonsense". With an ironic undertone, the author declared, "[...] we have learned to tolerate and even encourage daring analogizing in the search for new ideas - which is a way of getting extra mileage with the old ones. But we have also learned to mistrust analogy [...]: we want to go beyond resemblances" (Bunge 1967: 265).

Since his seminal book The Principles of Scientific Thinking (Harré 1970), Rom Harré has argued that the growing interest of the philosophy of science in models and modelling is a symptom of a general shift in the conception of scientific rationality that began in the 19th century. From a paradigm dominated by the ideal of "most general abstract forms of knowledge making", the focus shifted to a new paradigm in which 
[...] the principles of scientific were grounded in another kind of cognition, concrete representations of reality rather than abstract forms of the discourses. [...] The focus shifts from discourse, talking and writing about nature, the most general theory of which is logic, to modeling, the reproducing and representing nature materially, the most general theory of which is analogy. (Harré 2004: 3)

Tiles (1988) has substantiated Harrés account of this paradigm shift from symbolic to iconic discourse in science. In a paper with the title "Iconic thought and the scientific imagination", he compares the ideas and methodologies of two philosophers of the turn of the 19th to the 20th centuries, Pierre Duhem (1861-1916) and Charles S. Peirce (1839-1914) as prototypical representatives of the two paradigms distinguished by Harré. In The Aim and Structure of Physical Theory (1914), Duhem disparaged the use of models in scientific writing for its "unsuitability to constitute any element of a scientific theory" (Tiles 1988: 164). Sharing "Descartes's haughty disdain for the imagination that is linked to concrete objects", Duhem drew a "sharp distinction between reason and imagination" (Tiles 1988: 164). Duhem's antipode is Peirce: "Where Duhem contended that the products of the imagination are concrete and obstruct the process of generalization, Peirce argued [...] that as one can find a structure in a multitude of concrete phenomena, so one can find it in a concrete diagram" (Tiles 1988: 170).

The purpose of this paper has been to side with Peirce, to acknowledge that "imagination and imaging" are essential to model building (Morgan 2004), and to show why the opposition between symbolic and iconic thought is a false dichotomy.

\subsection{The semiotics of the "most perfect sign"}

In sum, models cannot fulfil their rhetorical function as mere symbols. A symbol in use must become mentally associated in its interpretant with icons and indices to become meaningful. Mere symbols are too abstract and too general to convey new information. "A symbol, in itself, is a mere dream; it does not show what it is talking about. For that purpose, an index is indispensable". Models need mental images and indices to relate its symbols to imagination and experience, for "a meaning is the association of a word with images, its dream exciting power", wrote Peirce in a paper not about fictional literature, but about "The Essence of Reasoning" (CP 4.56, 1893). Concerning the rhetorical efficiency of the icon, the index, and the symbol, Peirce also argues that icons and indices "are of the greatest utility and serve purposes that genuine signs [i.e., symbols, W. N.] could not" (EP 3: 306, 1904).

The capacity of diagrams to represent relations also explains how and why iconic models can enhance the rhetorical efficiency of scientific discourse. A clear argument 
is one that offers evidence, and "the evident is that which is presented in an image, leaving for the work of the understanding merely the Interpretation of the Image in a Symbol" (MS 339, microfilm 535, Sept 5, 1906).

Another reason why and how diagrammatic models are rhetorically efficient in furnishing evidence is that it is possible to derive information from them that the diagram itself does not have to make explicit because an iconic sign is in a sense self-explanatory. Peirce contrasts this quality of diagrams with the nature of dicent symbols, which are propositions or proposition-like signs. While a dicent is a "sign that conveys information" through the combination of its symbol with the index and the icon that it incorporates, an icon is a sign "from which information may be derived" (CP 2.309, 1902).

In a summary assessment of the rhetorical qualities of the three types of signs in relation to the object distinguished in his semiotic theory, Peirce writes,

The value of an icon consists in its exhibiting the features of a state of things regarded as if it were purely imaginary. The value of an index is that it assures us of positive fact. The value of a symbol is that it serves to make thought and conduct rational and enables us to predict the future. (CP 4.448, 1903)

Peirce concludes that the "most perfect" sign is one "in which the iconic, indicative, and symbolic characters are blended as equally as possible" (CP 4.448, 1903). This conclusion is perfectly valid for the rhetorical quality of scientific models, still today.

\section{References}

Achinstein, Peter 1965. Theoretical models. British Journal for the Philosophy of Science 16(62): 102-120.

Black, Max 1962. Models and Metaphors: Studies in Language and Philosophy. Ithaca: Cornell University Press.

- 1977. More about metaphor. Dialectica 31: 431-457.

Bunge, Mario Augusto 1967. Analogy in quantum theory: From insight to nonsense. British Journal of the Philosophy of Science 18: 265-286.

- 1973. Method, Model, and Matter. Dordrecht: Reidel.

Eco, Umberto 1998. Réflexion à propos du débat sur l'iconisme (1968-1998). Visio 3(1): 9-32.

CP = Peirce, Charles S. 1931-1958. Collected Papers of Charles S. Peirce (vols. 1-6, Hartshorne, Charles; Weiss, Paul, eds.; vols. 7-8, Burks, A. W., ed.). Cambridge: Harvard University Press. [In-text references are to $\mathrm{CP}$, followed by volume and paragraph numbers.]

Ciula, Arianna; Eide, Øyvind 2017. Modelling in digital humanities: Signs in context. Digital Scholarship in the Humanities 32, Suppl. 1.

EP 2 = Peirce, Charles Sanders. 1998. The Essential Peirce. Vol. 2. (Peirce Edition Project, ed.) Bloomington: Indiana University Press. 
Garnham, Alan; Oakhill, Jane 1996a. The mental models theory of language comprehension. In: Britton, Bruce K.; Graesser, Arthur C. (eds.) Models of Understanding Text. New York: Psychology Press, 313-339.

Garnham, Alan; Oakhill, Jane (eds.) 1996b. Mental Models in Cognitive Science. Hove: Psychology Press.

Goodman, Nelson 1976[1968]. Languages of Art: An Approach to a Theory of Symbols. (2nd ed.) Indianapolis: Hackett.

Graesser, Arthur C.; Swamer, Shane S.; Baggett, William B.; Sell, Maries A. 1996. New models of deep comprehension. In: Britton, Bruce K.; Graesser, Arthur C. (eds.), Models of Understanding Text. New York: Psychology Press, 1-32.

Haley, Michael Cabot 1988. The Semeiosis of Poetic Metaphor. Bloomington: Indiana University Press.

Harré, Rom 1970. The Principles of Scientific Thinking. Chicago: University of Chicago Press.

- 2004. Modeling: Gateway to the Unknown. (Rothbart, Daniel, ed.) Amsterdam: Elsevier.

Hesse, Mary 1963. Models and Analogies in Science. London: Sheed and Ward.

Houser, Nathan 1991. A Peircean classification of models. In: Anderson, Myrdene; Merrell, Floyd (eds.), On Semiotic Modeling. Berlin: Mouton de Gruyter, 431-439.

Hutten, Ernest H. 1953. The role of models in physics. British Journal for the Philosophy of Science 16: 284-301.

Johnson, Mark 1981. Introduction: Metaphor in the philosophical tradition. In: Johnson, Mark (ed.), Philosophical Perspectives on Metaphor. Minneapolis: University of Minnesota Press, 3-47.

Johnson-Laird, Philip N. 1980. Mental models in cognitive science. Cognitive Science 4: 71-115.

- 1983. Mental Models: Towards a Cognitive Science of Language, Inference, and Consciousness. Cambridge: Harvard University Press.

- 2010. Mental models and human reasoning. Proceedings of the National Academy of Sciences of the United States of America 107(43): 18243-18250.

Jones, Roger S. 1982. Physics as Metaphor. New York: Meridian.

Kralemann, Björn; Lattmann, Claas 2013. Models as icons: Modeling models in the semiotic framework of Peirce's theory of signs. Synthese 190: 3397-3420.

Lakoff, George; Johnson, Mark 1980. Metaphors We Live By. Chicago: University of Chicago Press.

Liddle, Stephen W. 2011. Model-driven software development. In: Embley, David W; Thalheim, Bernhard (eds.), Handbook of Conceptual Modeling. Heidelberg: Springer, 17-54.

Lotman, Juri M. 2011[1967]. The place of art among other modelling systems. Sign Systems Studies 39(2/4): 249-270.

Magnani, Lorenzo; Carnielli, Walter; Pizzi, Claudio (eds.) 2010. Model-Based Reasoning in Science and Technology: Abduction, Logic, and Computational Discovery. Berlin: Springer.

Magnani, Lorenzo; Bertolotti, Tommaso (eds.) 2017. Handbook of Model-Based Science. Berlin: Springer.

Mihram, Danielle; Mihram, G. Arthur. 1974. Human knowledge: The role of models, metaphors, and analogy. International Journal of General Systems 1: 41-60.

Morgan, Mary S. 2004. Imagination and imaging in model building. Philosophy of Science 71(5): 753-766. 
MS = Peirce, Charles Sanders 1979 [1963-1966]. The Charles S. Peirce Papers (30 reels, 3rd microfilm edition.) Cambridge: The Houghton Library, Harvard University, Microreproduction Service. [In-text references are to MS, followed by the manuscript numbers.]

Nagel, Ernest 1961. The Structure of Science: Problems in the Logic of Scientific Explanation. New York: Harcourt, Brace \& World.

NEM = Peirce, Charles Sanders 1976. The New Elements of Mathematics (4 vols.; Eisele, Carolyn, ed.) The Hague: Mouton. [In-text references are to NEM, followed by volume and page numbers.]

Nöth, Winfried 2006. Yuri Lotman on metaphors and culture as self-referential semiospheres. Semiotica 161: 249-263.

- 2010. The criterion of habit in Peirce's definitions of the symbol. Transactions of the Charles S. Peirce Society 46(1): 82-93.

- 2014. The growth of signs. Sign Systems Studies 42(2/3): 172-192.

- 2015. Three paradigms of iconicity research in language and literature. In: Hiraga, Masako K.; Herlofsky, William J.; Shinohara, Kazuko; Akita, Kimi (eds.), Iconicity: East Meets West, Amsterdam: Benjamins, 13-43.

ODE = Oxford Dictionary of English 2014. (Stevenson, Angus, ed.) Oxford: Oxford University Press.

Pola, Giordano; Pepe, Pierdomenico; Di Benedetto, Maria Domenica 2015. Symbolic models for time-varying time-delay systems via alternating approximate bisimulation. International Journal of Robust and Nonlinear Control 25: 2328-2347.

Quine, Willard Van Orman 1953. On what there is. In: Quine, Willard Van Orman, From a Logical Point of View. Cambridge: Harvard University Press, 1-19.

Rosenblueth, Arturo; Wiener, Norbert 1945. The role of models in science. Philosophy of Science 12(4): 316-321.

Santaella Braga, Lucia 2003. Why there is no crisis of representation, according to Peirce. Semiotica 143(1-4): 45-52.

Saussure, Ferdinand de 1969[1916]. Course in General Linguistics. (Baskin, Wade, trans.) New York: McGraw-Hill.

Sebeok, Thomas A. 1991. In what sense is language a 'primary modeling system'? In: Anderson, Myrdene; Merrell, Floyd (eds.), On Semiotic Modeling. Berlin: Mouton de Gruyter, 327-339.

Stahl, Lina Maria 2015. Zell-Modell und Modell-Zelle. Mikroskopische Bildgebung als Vorgang der Modellierung. In: Balke, Friedrich; Siegert, Bernhard; Vogl, Joseph (eds.), Modelle und Modellierung. München: Fink, 47-56.

Stjernfelt, Frederik 2007. Diagrammatology: An Investigation on the Borderlines of Phenomenology, Ontology, and Semiotics. Dordrecht: Springer.

Tchertov, Leonid 2015. On spatial modelling. Sign Systems Studies 43(1): 77-101.

Tiles, J. E. 1988. Iconic thought and the scientific imagination. Transactions of the Charles $S$. Peirce Society 24(2): 161-178.

Zeidler, Paweł 2013. Models and Metaphors as Research Tools in Science: A Philosophical Methodological and Semiotic Study of Science. Berlin: LIT. 


\section{Семиотика моделей}

В статье описывается понятие модели в научном дискурсе в перспективе семиотики Пирса и предлагается основа для определения разных типов моделей (включая ментальные). Автор критикует неоднородность критериев, применяемых в существующих типологиях моделей, и отсутствие семиотической базы в типологических различениях между формальными, символическими, теоретическими, метафорическими, иконическими и др. моделями. Утверждается, что применение пирсовского понимания знака как триады (сам знак, его объект и интерпретант) может способствовать более глубокому пониманию сущности моделей. В центре рассуждения - следующие семиотические темы: (1) различение моделей как знаков и (ментальных) моделей как интерпретантов; (2) модели как типы и модели как токены (или реплики); (3) иконичность моделей, в том числе диаграмматических и метафорических иконов; (4) вклад индексов и символов в информативность моделей и (5) риторические качества моделей в научном дискурсе. В заключении утверждается, что информативные модели являются гибридными знаками, в которых диаграмма включает в себя индексы и символы риторически эффективным образом.

\section{Mudelite semiootika}

Artikkel valgustab mudeli mõistet tavakeeles ja teadusdiskursuses C. S. Peirce'i semiootika perspektiivist lähtudes. Pakutakse välja Peirce'ilik üldraamistus mudelite, sealhulgas mentaalsete mudelite, defineerimiseks. Antakse ülevaade teaduslike mudelite definitsioonidest, mis on olnud mõjukad teadusfilosoofias, ja selles kontekstis esitatud tüpoloogiatest. Autor kritiseerib neis tüpoloogiates rakendatavate kriteeriumide heterogeensust ning semiootilise baasi puudumist tüpoloogilistes eristuses, sh formaalsete, sümboolsete, teoreetiliste, metafoorsete ja ikooniliste mudelite vahel. Artiklis väidetakse, et Peirce'i kolmetise märgiliigenduse (märgiks eneseks, selle objektiks ja tõlgendiks) rakendamine võib viia mudelite olemuse sügavamale mõistmisele. Semiootilised teemad, millele artiklis keskendutakse on (1) mudelite kui märkide ja (mentaalsete) mudelite kui märkide tõlgendite eristamine; (2) mudelid, mida peetakse tüübiks (või reegelmärgiks) ja mudelid, mida peetakse tüübi tookeniteks või koopiateks; (3) mudelite, sealhulgas diagrammatiliste ja metafoorsete ikoonide, ikoonilisus; (4) indeksite ja sümbolite panus mudelite informatiivsusesse; ja (5) mudelite retoorilised omadused teadusdiskursuses. Kokkuvõtes väidetakse artiklis, et informatiivsed mudelid on hübriidmärgid, milles diagramm hõlmab indekseid ja sümboleid retooriliselt tõhusal moel. 